\title{
Ensuring Basic Quality in Clinical Courses
}

\author{
Roy T. Stuckey*
}

Learning the law is easy. The difficult part of entering the legal profession is learning to be a lawyer. This is because the primary function of most lawyers is to help clients resolve their legal problems, and these problems do not come in neat, tidy packages like cases and statutes in law books. Nor do lawyers have law professors by their sides to help discover the right answers; they must figure out solutions on their own. Lawyers need an in-depth understanding of law and legal institutions, but they must also have specialized skills that enable them to apply that knowledge to the resolution of their clients' problems.

As members of the legal profession, lawyers are expected to have a clear understanding of and a commitment to the values of the legal profession and the standards of practice that guide lawyers' behavior. These values and standards are only partially expressed in the formal rules of legal ethics. The rest must be learned by word of mouth or by observing and participating in law practice. Personal characteristics such as integrity and good work habits, as well as professional virtues including loyalty to clients and zealous advocacy, are also indispensable traits of competent lawyers. Learning to be a lawyer is a life long activity that begins in law school.

Clinical education courses ${ }^{1}$ offer law students their first opportunities to discover firsthand how difficult it is to be a professional lawyer. Students can test and hone their knowledge and skills in clinical courses, but clinical education is especially valuable as a way for law schools to teach students the differences between professional and unprofessional behavior and to inspire them to become committed to the highest standards of practice. Students in clinical courses must move beyond theoretical discussions and apply their ideals about ethical standards in law practice settings. They learn about the standards of practice from other lawyers, who may or may not be members of a law faculty, and they observe the degree to which these standards are followed. One of the most valuable things about clinical education is that, unlike law practice, clinical courses allow students to discuss what they are learning and experiencing with other students and faculty, and often with practicing lawyers and judges.

* Alumni Professional Skills Professor of Law and Director of the Nelson Mullins Riley 8 Scarborough Center on Professionalism, University of South Carolina School of Law, USA

1 Some clinical courses are entirely simulated. Students are restricted to working on hypothetical problems. Other courses involve some simulated work and some exposure to actual law practice. When actual law practice is contemplated, this exposure might be provided through an externship course or through an inhouse clinic. Externships share some characteristics with in-house clinics, particularly the experience of practice. Externships, however, have two characteristics that distinguish them. First, the students' direct mentors/supervisors are not members of a law faculty but, instead, are practicing lawyers and judges. Second, students do not usually undertake primary responsibility for the representation of clients. 
This article describes some of the features of clinical course design that are essential for ensuring basic educational quality. It does not attempt to be thorough. A number of years ago, I served on a committee that began discussing whether it is possible to come up with "indicia of quality" that could be used to measure the quality of a clinical program or course. The question that framed the issue was "If someone wanted to determine whether one school's professional skills program is likely to be better than another school's program, what elements should be examined?" The committee not only guessed that it was possible to define those elements, we also believed that it could be accomplished without a great deal of trouble. Though I still think it is possible to define indicia of quality, we were wrong that it would be easy. Our initial effort foundered fairly quickly. From time to time others renewed the effort, only to abandon the project, with one exception. Sandy Ogilvy, a law professor at Catholic University School of Law in Washington, D.C., is making the most serious effort to date to describe "indicia of quality" for clinical programs.

The last time that I saw a draft of Professor Ogilvy's product was in September 1999. The document was titled Draft Guidelines/Standards for the Evaluation of Clinical Legal Education Programs. It was thirty-three single-spaced pages long, filled with one sentence statements of potential guidelines/standards related to educational quality and dealing with every imaginable aspect of clinical courses. It is a wonderful, thoughtfully-prepared document, and I look forward to seeing the next draft, although I think he has put the project aside for a while. I expect that it will eventually become an important document that clinical programs will use for self-evaluation purposes.

This article takes a very different approach than Professor Ogilvy's project. It describes only the most basic components for ensuring the educational quality of clinical courses. The insights in this article are neither profound nor novel, but they underscore the central elements of clinical education. The article may be useful to law schools that are thinking of establishing clinical courses, and it may help the rest of us remain focused on the fundamental reasons for law schools to offer clinical courses.

Clinical courses can take many forms and still accomplish important educational functions if they are thoughtfully designed. Various factors will affect how a clinical course is structured, most notably the preferences of the faculty and the resources of the school. Designing a clinical course provides opportunities for creative and new approaches, and very few clinical courses look exactly alike. Law schools, however, should approach clinical course design with care if they want to ensure that clinical students have the most effective educational experiences possible in relation to available resources.

It is a fair question to ask at this point why any structure is needed. Arguably, students will benefit from any chance they have to experience the real worlds of lawyers and judges, either as participants or observers. After all, it is often said that experience is the best teacher. It is probably impossible not to learn from experience, and it is equally likely that simply exposing students to the realities of law practice will benefit most of them in some way.

The real issue is not whether students can learn from unstructured clinical experiences. Of course they can. Rather, the key question is whether academic credit should be awarded to students who participate in clinical courses. The answer is that academic credit should be awarded only if a law school is prepared to establish clear educational objectives and to structure clinical courses in a way 
that will facilitate the achievement of those objectives. ${ }^{2}$ Experience acquired in a well-designed clinical course is the best teacher.

The importance of a law school establishing educational goals for clinical courses cannot be overemphasized, but it is equally important that clinical courses retain the flexibility to take advantage of unanticipated learning opportunities that arise during clinical courses. When students are exposed to the real world, they encounter things that neither they nor the faculty expects. These encounters often engage students' attention very significantly, and the structure of a clinical course should help students take advantage of opportunities to learn from unexpected and unplanned events.

Some students, either on their own or with encouragement from the law school, establish their own personal learning objectives upon enrolling in clinical courses. I view student-selected goals as supplemental to the educational objectives established by a law school, not as replacements for them. It is possible to conceive of a clinical course in which the only educational objectives are those that are set by the students. In this case, the clinical course would operate like a collection of independent study opportunities for students. There is no reason to prohibit students from pursuing personal educational objectives in clinical courses, and some good reasons exist to support them, so long as the law school ensures that the educational goals selected by the students are appropriate and that a reasonable plan and sufficient resources exist for accomplishing the student-selected goals as well as those established by the school.

I recognize that in some parts of the world, including some law schools in the United States, the primary motive for establishing clinical programs is to provide desperately needed legal services to people who cannot afford lawyers. The education of law students is a secondary consideration, although some valuable learning clearly occurs even in the most unstructured program. Providing free legal services to poor people is a worthy thing for everyone in the legal profession to support; however, I am personally critical of those who find it acceptable to put the burden of providing legal services to the poor on law students rather than on practicing lawyers. Even where service, not education, is the primary purpose of a clinical course, the essential components of structure that are outlined in this article should be employed. If for no other reason, the existence of these components will reduce the risk that clients will be harmed by the efforts of students, many of whom after all cannot be expected to render fully competent legal services because of their inexperience.

\section{Educational goals}

The educational goals of a clinical course should be determined by the mission of the law school, the interests of the faculty, and the needs of the students. Virtually any educational goal can be accomplished in a clinical course. Clinical education is a methodology, not a substantive topic of study. Clinical methods, however, are more suitable for accomplishing some specific educational goals than others. Many scholars have described the wide range of specific topics that are most

2 For a more thoughtful and thorough discussion of the importance of setting clear educational goals in clinical courses, see Peter T. Hoffman, Clinical Scholarship and Skills Training, 1 CLINICAL L. REV. 93 (1994). Professor Hoffman criticized law school clinics in the
United States for not setting clear educational objectives. In part because of Professor Hoffman's article, many clinical programs in the United States and around the world have established much clearer objectives. 
appropriately taught and learned in clinical courses. ${ }^{3}$ The following list describes what I believe are the five most important educational objectives that can be accomplished in clinical courses:

1. Developing problem-solving skills. A fundamental purpose of legal education is to teach students how legal problems are resolved through legal processes and to teach them what lawyers, judges, and other legal professionals actually do to help resolve them. Clinical courses can effectively help law schools achieve this central goal. Students in clinical courses, especially those involving actual law practice, experience the multitudes of factors that affect decisionmaking, and they begin to understand the relationships of the factors and how they can help or hinder problem-solving. They begin to see how the pieces fit together, and they begin developing legal problem-solving skills.

2. Becoming more reflective about legal culture and lawyering roles. Students in clinical programs develop a better sense of their strengths and weaknesses as lawyers. They also become more aware of the social experience, institutions, and interactions that comprise the legal culture. Students' clinical experiences form the basis for insights into the functioning of the legal system and raise questions about the legal system's capacities and limitations. Clinical students also learn how the law in action actually operates and what lawyers can accomplish in the world and what they cannot.

3. Learning how to behave as well as how to think like a lawyer. Clinical courses give students opportunities to perform in professional roles or to observe lawyers practicing litigation skills or pretrial lawyering skills such as interviewing, counseling, negotiating, and drafting. Students in clinical courses are confronted with professional responsibility issues that must be resolved, not just discussed. Thus, clinical courses increase students' sensitivity and awareness about ethical and moral dilemmas that lawyers regularly face and resolve, and they begin developing personal systems of professional values and responsibility.

Clinical courses expose students to the demands, constraints, and methods of analyzing and dealing with unstructured situations in which the issues have not been identified in advance. They learn how to transform the analytical aspects of lawyers' work into predictive decisionmaking capabilities for counseling clients and resolving clients' problems in a manner that is consistent with the relationship, role, and responsibility of the lawyer to society, clients, and the legal process.

Clinical students begin to understand the difference between professional and unprofessional behavior. They learn the importance of the following characteristics of professionalism, to name only a few: client-centered practice; civility and fair play; doing good and doing well; honesty, diligence, perseverance, creativity, hard-work, adaptability, responsibility, toughness, timeliness, character, good judgment, and honor.

3 See William P. Quigley, Introduction to Clinical Teaching for the New Clinical Law Professor: A View from the First Floor, 28 AKRON L. REV. 463 (1995); Report of the Committee on the Future of the In-House Clinic, 42 J. LEGAL EDUC. 508 (1992); Carrie Menkel-Meadow, Two Contradictory Criticisms of Clinical Education: Dilemmas and Directions in Lawyering Education, 4 ANTIOCH L.J. 287 (1986);
Frank S. Bloch, The Andragogical Basis of Clinical Legal Education, 35 VAND. L. REV. 321 (1982); Committee on Guidelines for Clinical Legal Education, AALS-ABA, Clinical Legal Education (1980); E. Gordon Gee 8 Donald W. Jackson, Bridging the Gap: Legal Education and Lawyer Competency, 1977 BYU L. REV. 695. 
4. Understanding the meaning of justice and the responsibility of all lawyers to strive to do justice. Clinical students learn more about justice in their society from their clinical experiences than any book could teach them. They gain insights into what justice is, why it is important, what systems exist for adjudicating disputes, and the roles and limitations of lawyers and judges in securing justice. They learn to appreciate the importance of the rule of law for ensuring justice in a society.

In 1990, Professor David Barnhizer called on law schools to conceive of clinical programs as symbols and models of justice in action:

"Law faculties have the obligation to insist that students pursue the concerns of justice and their professional responsibility because justice is not simply an intriguing intellectual issue, but is a fundamental part of stability of any society. Force can substitute for justice to some extent in dictatorial or autocratic societies, but in democratic societies it is not the sterility of law or the reality of brute individual power, but the viability of justice that determines these societies' ultimate quality and fairness. Failing to confront people and institutions who are responsible for injustice shirks the central responsibility of the modern intellectual, that of "speaking truth to power." Unwillingness to develop such fundamental issues with law students, both in traditional courses and in clinical courses, undermines ... society's ability to deal with difficult questions." ${ }^{4}$ If a law school wants to teach students about justice, clinical courses can play a major role by focusing on the processes, values, and actions involved in "doing justice."

5. Discovering the human effects of the law. Clinical courses allow students to begin examining the interaction of legal analysis and human behavior, including interpersonal dynamics and communication. They learn how the law affects people's lives by bringing hope or fear, sadness or joy, pain or relief, frustration or satisfaction. They learn that the actual results of legal processes are often not the same as predicted by an objective analysis of the facts and law because of the biases and perceptions as well as the relative skills and knowledge of lawyers, judges, clients, and witnesses.

Many clinical students observe the realities of poverty through clinical programs. They learn to serve the unmet legal needs of the poor, and they develop an appreciation of the importance and benefits of providing pro bono representation to those who would not otherwise have access to the legal system.

The remainder of this article discusses how clinical courses can be structured to achieve these basic educational objectives consistently.

\section{Structuring Clinical Courses to Achieve Basic Objectives}

The structure of a clinical course is shaped by the specific educational goals of the course. Like any other course, the objective in designing a clinical course is to provide students with an organized and focused, not a haphazard, learning experience. It is beyond the scope of this article to discuss how a specific clinical course should be structured. There are simply too many potential educational goals to consider and too many potential ways to deliver instruction about them.

4 David Barnhizer, The University Ideal and Clinical

Legal Education, 35 NYLS L. REV. 87, 112-113

(1990). 
Two components must be in place, however, to accomplish consistently the educational goals of clinical education that were described earlier. These are effective instruction in problem-solving and guidance by qualified mentors and faculty.

Effective instruction in problem-solving requires first and foremost that students be given opportunities to engage in problem-solving in context. Problem-solving skills are developed by actually working through the process of resolving problems. Repetition and learning in context are essential ingredients for becoming an expert problem-solver. Law students begin law school with innate problem-solving skills that were acquired throughout their lives. Legal problems, however, present new challenges that require law students to acquire and apply different forms of analytical skills than nonclinical law school courses teach. ${ }^{5}$ Novice problem-solvers approach problemsolving differently than experienced problem-solvers, and students can only become expert problem-solvers through repeated efforts to resolve law-related problems. ${ }^{6}$

No single course during law school can turn a novice problem-solver into an expert problemsolver. It is unlikely that many students will graduate from law school as expert, or even competent, problem-solvers. They simply do not have enough time to refine their skills during law school. However, they can graduate with some experience in legal problem-solving and become closer to the goal of mastering the skill. It is important, though, that students begin honing their legal problem-solving skills during law school, and that they at least become familiar with the four phases of problem-solving: (1) determining exactly what the problem is that needs to be solved and identifying alternative solutions that might resolve the problem and the potential consequences of each (diagnostic or analytical phase); (2) deciding which alternative solution, or prioritized series of solutions, to apply to the problem and how to do so (prescriptive or planning phase); (3) executing the plan (treatment or action phase); and (4) reflecting on the process and results and determining whether additional work is needed (follow-up or reflective phase). ${ }^{7}$

5 Tony Amsterdam points out that legal education traditionally taught six or seven kinds of analytic reasoning to the exclusion of fifteen or twenty others. He describes three that were traditionally taught (case reading and interpretation, doctrinal analysis and application, logical conceptualization and criticism) and three that were not traditionally taught before clinical courses were introduced into the law school curriculum (ends-means thinking, hypothesis formulation and testing in information acquisition, decision making in situations where options involve differing and often uncertain degrees of risks and promises of different sorts). Anthony G. Amsterdam, Clinical Legal Education - A 21st Century Perspective, 34 J. LEGAL EDUC. 612, 613-614 (1984).

6 For an extensive discussion from a behavioral science perspective of the problem-solving process and how novice problem-solvers become expert problem-solvers, see Gary L. Blasi, What Lawyers Know: Lawyering Expertise, Cognitive Science, and the Functions of Theory, 45 J. LEGAL EDUC. 313 (1995).

7 This particular description of the problem-solving process is the author's own formulation. Stephen
Nathanson's adaptation of generic problem-solving theory to legal problems produced a five step description of the problem-solving process: problem and goal identification, fact investigation, legal issue identification and assessment, advice and decision making, planning and implementation. Stephen Nathanson, The Role of Problem Solving in Legal Education, 39 J. LEGAL EDUC. 167, 172 (1989). The MacCrate Report uses a slightly different description of the problem-solving process: identifying and diagnosing the problem, generating alternative solutions and strategies, developing a plan of action, implementing the plan, and keeping the planning process open to new ideas. TASK FORCE ON LAW SCHOOLS AND THE PROFESSION: NARROWING THE GAP, ABA, LEGAL EDUCATION AND PROFESSIONAL DEVELOPMENT: AN EDUCATIONAL CONTINUUM (MacCrate Report) (1992) at 138, 141-148. Neither Nathanson nor the MacCrate Report includes reflective evaluation in their descriptions of the process, but cognitive scientists stress its importance for developing problem-solving expertise. Blasi, supra note 6, at 360 . 
The second essential component of every clinical course is the participation of qualified teachers or mentors who guide the students' work. For example, instruction in problem-solving skills cannot be effective, unless one or more qualified people are responsible for (1) selecting and assigning the problems that students will be asked to solve, (2) ensuring that students have sufficient knowledge and skills to solve the types of problems being assigned, (3) helping students figure out during the problem-solving process how to resolve aspects of the problems that are beyond their abilities, and (4) facilitating reflective thought by students about the process and results. These tasks might be accomplished by a single teacher or by a team of teachers, including law school faculty and practicing lawyers and judges. While the degree of direct involvement may vary, the ultimate responsibility for the achievement of the educational goals should always remain with the full-time faculty.

In all aspects of a clinical course, students need access to people who can help them learn what it means to become a member of the legal profession. Thus, the lawyers, judges, and faculty who work with clinical students must understand and adhere to the values of the legal profession and the standards of practice that guide the behavior of lawyers. It is critically important that the people who are responsible for directing students in clinical courses model personal characteristics such as integrity and good work habits. They should also be able to explain the importance of professional virtues such as loyalty to clients and zealous advocacy and how these and other professional virtues affect the decisions of lawyers who are trying to resolve problems that are similar to those the students are encountering. If a law school wants its students to become committed to doing justice, or to pro bono representation and public service activities, the law school must ensure that the people who guide clinical students' activities share those commitments.

\section{Conclusion}

Law schools throughout the world are increasingly recognizing the importance of providing more well-rounded programs of instruction to improve the readiness of law students to enter the legal profession. Given the limited amount of time that students attend law school, law schools must make difficult choices about the allocation of resources and the types of educational opportunities that will be provided to students. Clinical legal education is an effective, efficient method for delivering instruction that complements the traditional curriculum and eases students' transition into law practice. The basic educational quality of clinical courses will be ensured if law schools establish appropriate educational goals, give students opportunities to engage in problem-solving in context, and involve lawyers, judges, and faculty who are qualified to help students learn what it means to be a professional lawyer. 